\title{
Kaolin Clay Consumption and Pregnancy: Prevalence, Hematological Consequences and Outcome of Labour in the Douala
}

\author{
Henri Essome1,2, Jean Paul Engbang1,2, Gaëlla Ndedi Penda², Mve Koh Valere ${ }^{3,4}$, Merlin Boten1, \\ Pascal Foumane $^{4,5}$, Dieudonné Adiogo ${ }^{2}$ \\ ${ }^{1}$ Douala Laquintinie Hospital, Douala, Cameroon \\ ${ }^{2}$ Faculty of Medicine and Pharmaceutical Sciences, The University of Douala, Douala, Cameroon \\ ${ }^{3}$ Yaounde University Health Center, Yaoundé, Cameroon \\ ${ }^{4}$ Faculty of Medicine and Biomedical Sciences, The University of Yaoundé I, Yaoundé, Cameroon \\ ${ }^{5}$ Gynecological-Obstetric and Pediatric Hospital of Yaoundé, Yaoundé, Cameroon \\ Email: jean_pen@yahoo.ca
}

How to cite this paper: Essome, H., Engbang, J.P., Penda, G.N., Valere, M.K., Boten, M., Foumane, P. and Adiogo, D. (2017) Kaolin Clay Consumption and Pregnancy: Prevalence, Hematological Consequences and Outcome of Labour in the Douala. Open Journal of Obstetrics and Gynecology, 7, 1166-1173.

https://doi.org/10.4236/ojog.2017.712118

Received: October 9, 2017

Accepted: November 7, 2017

Published: November 10, 2017

Copyright $\odot 2017$ by authors and Scientific Research Publishing Inc. This work is licensed under the Creative Commons Attribution International License (CC BY 4.0).

http://creativecommons.org/licenses/by/4.0/

\section{(c) (i) Open Access}

\begin{abstract}
Objective: To determine the prevalence, haematological repercussions and prognosis of childbirth in the event of consumption of kaolin during pregnancy. Materials and Methods: It was a study over a period of 3 months at the Laquintinie Hospital Douala. It compared two groups of women, one of whom had consumed kaolin during pregnancy (exposed group) and the other had not consumed it (non-exposed group). Results: A total of 342 women were included in our study, 121 (35.4\%) of whom had consumed kaolin during pregnancy. Women exposed to this consumption $(\mathrm{P}<0.05)$ after univariate analysis were those of pregnant women from the Far North $(\mathrm{OR}=3.37$, CI: $1.29-8.79, \mathrm{P}=0.013)$, single $(\mathrm{OR}=1.65, \mathrm{CI}=1.05-2.59, \mathrm{P}=0.029)$, those with primary education $(\mathrm{OR}=2.25, \mathrm{CI}=1.06-4.79, \mathrm{P}=0.035)$ and those with HIV $(\mathrm{OR}=2.75, \mathrm{IC}=1.02-7.43, \mathrm{P}=0.045)$. Consumption was more frequent in the first trimester of pregnancy (37\%) and in the third quarter $(34 \%)$, at a predominantly weekly rate $(47.9 \%)$. The most frequently cited reasons were envy $(82 \%)$, and nausea (45\%). This consumption was associated with a risk of premature delivery $(\mathrm{RR}=2.26, \mathrm{IC}=1.27-4.05, \mathrm{P}=0.001)$, yellowish amniotic fluid $(\mathrm{RR}=4.66, \mathrm{IC}=1.81-11, \mathrm{P}=0.001)$, birth weight $<$ $2500 \mathrm{~g}$ in newborns $(\mathrm{RR}=1.72, \mathrm{IC}=3.36-9.56, \mathrm{P}=0.025)$, but increased the probability of delivery $(\mathrm{RR}=1.94, \mathrm{IC}=0.96-3.90, \mathrm{P}=0.039)$. For the hematological aspect, the occurrence of anemia $(\mathrm{RR}=1.55, \mathrm{IC}=0.97-2.31, \mathrm{P}=$ $0.003)$ and a decrease in mean hemoglobin concentration $(\mathrm{RR}=1.29, \mathrm{IC}=$ $0.83-2.03, \mathrm{P}=0.041)$ were associated with kaolin in pregnancy. After multi-
\end{abstract}


variate logistic regression, the complications included premature delivery, yellowish colour of the amniotic fluid and decreased hemoglobin. Conclusion: The use of kaolin is a frequent feeding behavior in pregnancy, mainly motivated by envy, which nevertheless presents serious maternal and fetal complications.

\section{Keywords}

Kaolin, Pregnancy, Anemia, Prognosis, Childbirth, Douala

\section{Introduction}

Eating disorders are widespread throughout the world, represented by pathologies such as geophagia, bulimia and anorexia [1]. Geophagy is defined as the voluntary feeding of land between $10-50 \mathrm{~g}$ per day [2]. It represents the most widespread form of pica; the practice of ingesting non-edible materials [1]. It is one of the nutritional disorders frequently occurred in pregnant women [1]. The kaolin locally called "kalaba" is the material of predilection of the geophages. It is more or less sweet, white or pinkish clay frequently consumed in Africa, rarely in India and the USA [3]. It is believed to have antiparasitic, antidiarrheal, and especially antacid properties [4]. Nevertheless, because of its remarkable ion-exchange properties, its consumption would upset the absorption of ions, causing deficiencies, mainly iron responsible for long-term iron deficiency anemia [5]. Its consumption is also responsible for other pathologies such as poisoning with heavy metals, pesticides, intestinal occlusions and renal lithiasis [6]. Studies in Africa on geophagia and pregnancy show prevalence of $65 \%, 28 \%$ and $50 \%$ respectively in Kenya, Tanzania and Nigeria [6] [7]. A study carried out in Yaoundé gives a prevalence of consumption of kaolin in pregnancy in the percentage of 32.4\% [8]. Because of the iron chelating properties of kaolin, its consumption makes it one of the etiologies encountered but little known of iron deficiency anemia [5]. Iron deficiency anemia is a condition affecting $20 \%$ of pregnant women in developed countries, $51 \%$ in developing countries [9]. A study carried out in Douala on the prevalence of anemia in pregnancy, evaluated it at 20.5\% [10]. Nevertheless, the relationship between anemia and soil ingestion is not yet well established. It would be a vicious circle, where ingestion of soil would lead to anemia due to iron deficiency, which would increase the urge to consume soil [5]. As part of our contribution to the knowledge of geophagy and its consequences, we proposed to carry out this work, which aimed to investigate the hematological repercussions and the prognosis of childbirth in the case of geophagic practice among pregnant women in the maternity of Douala Laquintinie Hospital.

\section{Methods}

It was a study conducted at the Douala Laquintinie Hospital over a period of 
about 3 months; from 21 February to 31 May 2017. All pregnant women were included, with the exception of those with increased risk factors for bleeding. Two groups were then constituted, one consuming kaolin and the other not have being consuming. Consumption information, socio-demographic data, medical and obstetric history, labor and blood count were collected. The study materials were an established standardized questionnaire and the result of a biological sampling (NFS) at the time of delivery. The statistical analyses were done by SPSS software version 20.0. The associated factors were investigated using the logistic regression method in univariate and multivariate analysis. The Odds Ratio (OR) and Relative Risk (RR) were used to measure the degree of association. The significance threshold was set at $\mathrm{P}<0.05$.

\section{Results}

During our study period, we identified 353 female workers in the laboratory, after searching for exclusion criteria. 342 were retained, including 121 kaolin users, a prevalence of $35.4 \%(\mathrm{~N}=342)$ (Figure 1 ). For the population consuming kaolin, the most represented age group was [25 - 35] years with an average of 26 \pm 4 years. The main reason for consumption was envy (82\%) with a predominance in the first quarter (56.4\%) weekly $47.9 \%$ (Table 1).

Sociodemographic data and antecedents: Sociodemographic variables and antecedents revealed that belonging to the Far North region $(\mathrm{OR}=3.37, \mathrm{CI}: 1.29$ $8.79, \mathrm{P}=0.013)$, single marital status $(\mathrm{OR}=1.65, \mathrm{CI}: 1.05-2.59, \mathrm{P}=0.029)$, primary education $(\mathrm{OR}=2.25, \mathrm{CI}: 1.06-4.79 ; \mathrm{P}=0.035)$ and HIV carriers (OR $=2.75, \mathrm{CI}: 1.02-7.43, \mathrm{P}=0.045)$ predisposed to kaolin in pregnancy (Table 2 ).

Childbirth labor: After univariate analysis, labor-related variables associated with consumption of kaolin were: prematurity $(\mathrm{RR}=2.26, \mathrm{IC}: 1.27-4.05, \mathrm{P}=$ $0.001)$, yellowish coloration $(\mathrm{RR}=1.94, \mathrm{IC}=0.96-3.90, \mathrm{P}=0.001, \mathrm{P}=0.001)$ $0.039)$, birth weight $<2500 \mathrm{~g}(\mathrm{RR}=1.72$, IC: 3.36 - 9.56, $\mathrm{P}=0.025)$.

The use of kaolin protects against complications such as: caesarean section $(\mathrm{RR}=0.61, \mathrm{IC}: 0.35-1.04, \mathrm{P}=0.016)$ and cephalo-pelvic disproportion $(\mathrm{RR}=$ $0.29,10-0.86, \mathrm{P}=0.017$ ) (Table 3 ).

$\mathrm{N}=342$

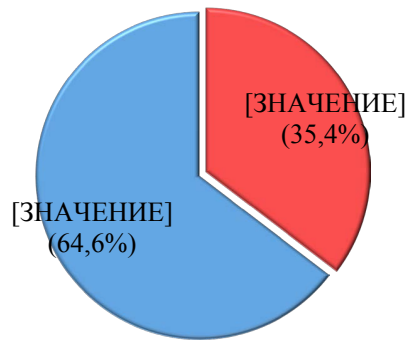

日Consommation $\quad$ Non consommation

Figure 1. Prevalence of consumption of kaolin. 
Table 1. Distribution by kaolin consumption variables.

\begin{tabular}{ccc}
\hline Variables & Effective & Percentage \\
\hline Term of the consumption & 5 & 4.1 \\
Before pregnancy & 68 & 56.2 \\
1st trimester & 48 & 39.7 \\
2nd trimester & 64 & 52.9 \\
3rd trimester & & \\
Fréquency of the consumption & 47 & 38.8 \\
Per day & 58 & 47.9 \\
Per week & 11 & 9.1 \\
Per month & 5 & 4.1 \\
Per trimester & & \\
Notivations of the consumption & 54 & 44.6 \\
Nausea & 3 & 2.5 \\
Vomiting & 99 & $\mathbf{8 1 . 8}$ \\
Desire & 1 & 0.8 \\
Culture & 1 & 0.8 \\
No reason & &
\end{tabular}

Table 2. Summary of socio-demographic and history variables with a significant association with consumption of kaolin.

\begin{tabular}{ccccc}
\hline Variables & $\begin{array}{c}\text { Exposed } \\
\mathbf{N}=\mathbf{1 2 1}\end{array}$ & $\begin{array}{c}\text { Non-exposed } \\
\mathbf{N}=\mathbf{2 2 1}\end{array}$ & OR (IC 95\%) & P value \\
\cline { 2 - 5 } & $\mathbf{n}(\%)$ & $\mathbf{n}(\%)$ & & \\
\hline $\begin{array}{c}\text { Extreme North } \\
\text { Region }\end{array}$ & $12(9.9)$ & $7(3.2)$ & $3.37(1.29-8.79)$ & $\mathbf{0 . 0 1 3}$ \\
$\begin{array}{c}\text { Single } \\
\text { Primary }\end{array}$ & $73(60.3)$ & $106(48.0)$ & $1.65(1.05-2.59)$ & $\mathbf{0 . 0 2 9}$ \\
HIV & $16(13.2)$ & $14(6.3)$ & $2.25(1.06-4.79)$ & $\mathbf{0 . 0 3 5}$ \\
\hline
\end{tabular}

1. Human immunodeficiency virus.

Table 3. Summary of childbirth labor variables with a significant association with consumption of kaolin.

\begin{tabular}{ccccc}
\hline \multirow{2}{*}{ Variables } & $\begin{array}{c}\text { Exposed } \\
\mathbf{N}=\mathbf{1 2 1}\end{array}$ & $\begin{array}{c}\text { Non-exposed } \\
\mathbf{N}=\mathbf{2 2 1}\end{array}$ & RR (IC 95\%) & P value \\
\cline { 2 - 5 } & $\mathbf{n}(\%)$ & $\mathbf{n}(\%)$ & & \\
\hline GA $^{1}<$ 37WA & & & \\
Yellowish Amniotic Fluid & $31(25.6)$ & $25(11.3)$ & $2.26(1.27-4.05)$ & $\mathbf{0 . 0 0 1}$ \\
Vaginal delivery & $16(13.2)$ & $7(3.2)$ & $4.66(1.81-11.33)$ & $\mathbf{0 . 0 0 1}$ \\
caesarean & $96(79.3)$ & $150(67.9)$ & $1.72(3.36-9.56)$ & $\mathbf{0 . 0 2 5}$ \\
CSD $^{3}$ & $24(19.8)$ & $71(32.1)$ & $0.61(0.35-1.04)$ & 0.016 \\
BW $^{4}<2500$ & $4(3.3)$ & $25(11.1)$ & $0.29(0.10-0.86)$ & 0.017 \\
\hline
\end{tabular}

1. Gestational age; 2. Weeks of amenorrhea; 3. Cerebrospinal dystocia; 4. Birth weight; 5. Average corpuscular concentration in hemoglobin. 
Blood count: Consumption of kaolin increases the risk of hypochromic anemia, which is objectified (Table 4) by a statistically significant association between kaolin intake and a decrease in hemoglobin to less than $10(\mathrm{RR}=1.55$, IC $=0.97-2.31, \mathrm{P}=0.003)$ and on the other hand a decrease in mean corpuscular hemoglobin concentration $(\mathrm{RR}=1.29, \mathrm{IC}=0.83-2.03, \mathrm{P}=0.041)$.

After multivariate analysis using linear logistic regression, the factors independently associated with consumption of kaolin were: being from the extreme North region, single marital status, prematurity and anemia (Table 5).

Table 4. Breakdown by blood count.

\begin{tabular}{|c|c|c|c|c|}
\hline \multirow{2}{*}{ Variables } & $\begin{array}{l}\text { Exposed } \\
\mathrm{N}=121\end{array}$ & $\begin{array}{c}\text { Non-exposed } \\
\mathrm{N}=\mathbf{2 2 1}\end{array}$ & RR (IC 95\%) & \multirow[t]{2}{*}{$P$ value } \\
\hline & n (\%) & n (\%) & & \\
\hline \multicolumn{5}{|l|}{ Hemoglobin $(\mathrm{g} / \mathrm{dl})$} \\
\hline$<10.5$ & $56(46.3)$ & $66(29.9)$ & $1.55(0.97-2.31)$ & \multirow{2}{*}{0.003} \\
\hline$\geq 10.5$ & $65(53.7)$ & $155(70.1)$ & $0.76(0.48-1.21)$ & \\
\hline \multicolumn{5}{|l|}{$\mathrm{MCH}^{1}(\mathrm{pg})$} \\
\hline$<24$ & $15(12.4)$ & $21(9.5)$ & $1.31(0.65-2.63)$ & 0.406 \\
\hline $24-37$ & $193(87.3)$ & $102(84.3)$ & $0.96(0.52-1.79)$ & 0.437 \\
\hline$\geq 37$ & $4(3.3)$ & $7(3.2)$ & $1.05(0.30-3.63)$ & 0.945 \\
\hline \multicolumn{5}{|l|}{$\operatorname{MCHC}^{2}\left(\mathrm{~g}^{\bullet} / \mathrm{dl}\right)$} \\
\hline$<32$ & $76(62.8)$ & $135(61.1)$ & $1.03(0.65-1.62)$ & 0.754 \\
\hline $32-36$ & $32(26.4)$ & $63(28.5)$ & $0.93(0.56-1.52)$ & 0.684 \\
\hline$\geq 36$ & $13(10.7)$ & $23(10.4)$ & $1.04(0.51-2.11)$ & 0.923 \\
\hline \multicolumn{5}{|l|}{ Hematocrit (\%) } \\
\hline$<34$ & $61(50.4)$ & $86(38.9)$ & $1.29(0.83-2.03)$ & \multirow{2}{*}{0.041} \\
\hline$\geq 34$ & $60(49.6)$ & $135(61.1)$ & $0.81(0.52-1.27)$ & \\
\hline \multicolumn{5}{|l|}{$\mathrm{MGV}^{3}(\mathrm{fl})$} \\
\hline$<80$ & $18(14.9)$ & $28(12.7)$ & $1.18(0.62-1.64)$ & 0.568 \\
\hline $80-100$ & $86(71.1)$ & $155(70.1)$ & $1.01(0.62-1.64)$ & 0.856 \\
\hline$\geq 100$ & $17(14.0)$ & $38(17.2)$ & $0.82(0.44-1.51)$ & 0.450 \\
\hline \multicolumn{5}{|c|}{ White blood cells $\left(\mathrm{C} / \mathrm{mm}^{3}\right)$} \\
\hline$<15,000$ & $108(89.3)$ & $209(94.6)$ & $0.94(0.41-2.13)$ & 0.076 \\
\hline$\geq 15,000$ & $12(10.7)$ & $13(10.7)$ & $1.88(0.83-4.25)$ & \\
\hline \multicolumn{5}{|l|}{ Platelets $\left({ }^{\circ} \mathrm{C} / \mathrm{mm}^{3}\right)$} \\
\hline$<150,000$ & $19(15.7)$ & $56(25.3)$ & $0.62(0.35-1.11)$ & 0.549 \\
\hline $15,000-450,000$ & $99(81.8)$ & $164(74.2)$ & $1.10(0.64-1.92)$ & 0.112 \\
\hline$\geq 450,000$ & $3(2.5)$ & $1(0.5)$ & $5.62(0.57-53.11)$ & 0.138 \\
\hline
\end{tabular}

1. Mean corpuscular hemoglobin (MCH); 2. Mean corpuscular hemoglobin concentration; 3. Mean globular volume. 
Table 5. Multivariate logistic regression.

\begin{tabular}{ccccc}
\hline \multirow{2}{*}{ Variables } & OR adjusted & \multicolumn{2}{c}{ IC. 95\% } & P value \\
\cline { 2 - 5 } & & Inferior & Superior & \\
\hline Extreme North & 6.69 & 2.05 & 21.90 & $\mathbf{0 . 0 0 2}$ \\
Signle & 2.02 & 1.20 & 3.37 & $\mathbf{0 . 0 0 8}$ \\
Primary & 1.61 & 0.64 & 4.07 & 0.311 \\
HIV & 1.95 & 0.64 & 5.97 & 0.242 \\
Prématurité & 2.57 & 1.08 & 6.13 & $\mathbf{0 . 0 3 3}$ \\
Weight < 2500 grs & 0.60 & 0.20 & 1.74 & 0.346 \\
Yellowish Amniotic Fluid & 4.59 & 1.65 & 12.78 & $\mathbf{0 . 0 0 4}$ \\
Vaginal delivery & 1.46 & 0.77 & 2.78 & 0.250 \\
Hematocrit & 1.01 & 0.55 & 1.83 & 0.986 \\
Hemoglobin < 10.5 & 2.07 & 1.11 & 3.86 & $\mathbf{0 . 0 2 1}$ \\
\hline
\end{tabular}

1. Human immunodeficiency virus.

\section{Discussion}

Our study found a $35.4 \%$ prevalence of consumption of kaolin in pregnancy (Figure 1). This consumption was spread over the whole pregnancy with a predominance in the first quarter (37\%) and the third quarter (34\%). It was more frequent during the week and envy was the main reason for this practice at $82 \%$ followed by relief of nausea (Table 2).

These data are in line with studies conducted in Yaoundé in 2015 and 2016, which stipulate that the consumption of kaolin has a prevalence of $32.4 \%$ and $40.5 \%$ respectively. The consumption pattern was $49.50 \%$ and $55 \%$, respectively [8] [11].

Here, the labor of childbirth and the fate of the newborn were studied. 16.37\% of the admitted pregnant women had a gestational age of less than 37weeks. Kaolin intake after univariate analysis was found to be a factor that multiplied the risk of premature birth by $2(\mathrm{RR}=2.26, \mathrm{CI}: 1.27-4.05, \mathrm{P}=0.001)$.

The color of the amniotic fluid was also influenced by the kaolin intake. An increase in the frequencies of amniotic fluid, yellowish colour and meconium, was observed when consumption of kaolin was observed. This practice had a deleterious effect on the color of the amniotic fluid $(\mathrm{RR}=4.66, \mathrm{CI}$ : $1.81-11.83, \mathrm{P}=$ 0.001 ); with a four-fold increase in the risk of having a yellowish amniotic fluid at childbirth.

The birth weight of our series varied between 700 - 5600 grams and was negatively influenced by consumption. Women Consuming kaolin were 1.72 times more likely to have a newborn baby weighing less than 2500 grams $(R R=1.72$, CI: 3.36 - 9.56, P = 0.025).

The geophagic practice had the advantage of reducing the risk of an indication of Caesarean section. There was an increase in delivery by low route in the case of kaolin intake ( $R R=1.94$, IC: $0.96-3.90, P=0.039)$. 
All these findings go in the same direction as the literature, which reports that geophagy exposes to the risks of premature birth, newborns with low birth weight. Data reported by Njiru in Kenya in 2011 and Foumane et al. in Yaoundé in 2016 indicate that consumption of kaolin was associated with newborns with weight under 2500 grams [11] [12]. This is due to a decrease in maternal-fetal blood flow due to maternal anemia. With a chronic fetal suffering partly explaining prematurity; the yellowish amniotic fluid, and the small birth weight (which itself favors the passage through the lower lobe) at the time of delivery.

On our population of 342 pregnant women, $123 \mathrm{had}$ an $\mathrm{Hb}<10.5 \mathrm{~g} / \mathrm{dL}$. After logistic analysis, we found that consumption of kaolin increased the risk of anemia $(R R=1.55, I C: 0.97-2.31, P=0.003)$. The literature goes in the same direction, in that a study carried out in Madagascar in 2011 on the relationship between geophagy and anemia shows us a case of carotid anemia resulting from geophagy with a hemoglobin $<9 \mathrm{~g} / \mathrm{dL}$ [13]. Similarly, a cohort study carried out in 2009 in western Guyana on 109 female geophages and 75 non-geophages showed a hemoglobin $<8.5 \mathrm{~g} / \mathrm{dL}$ at the beginning of pregnancy, with a progressive decrease during pregnancy, requiring transfusion of the globular pellet [5]. This is explained by the iron chelating action of kaolin.

\section{Conclusion}

Consumption of kaolin is a common practice during pregnancy in Africa. The origin of extreme north, the celibacy and the prematurity are the independent factors associated with kaolin intake in this study.

\section{References}

[1] Gueslin, J.-P. and Gueslin, J.P. (2005) Sémiologie des troubles du comportement alimentaire (T.C.A) de l'adolescent et de l'adulte. [Semiology of Eating Disorders in Adolescents and Adults.] Module Science, Faculté de médecine de Bobigny. https://www.yumpu.com/fr/document/view/16712557/semiologie-des-troubles-ducomportement-alimentaire-tca-free

[2] Cardwell, M. (2013) Eating Disorders during Pregnancy. Obstetrical \& Gynecological Survey, 68, 312-323. https://doi.org/10.1097/OGX.0b013e31828736b9

[3] Pessoa, G. (2008) Le goût de l'argile. [The Taste of Clay.] Terrains \& Travaux, 9, 177-191.

[4] Rautureau, M., Allègre, J., Liewig, N. and Katouzian-Safadi, M. (2008) Géophagie: Pica, pharmacologie ou nécessité vitale. [Geophagy: Pica, Pharmacology or Vital Necessity.] Réunion des sciences de la terre, Nancy. http://www.jade-allegre.com/publications/geophagie.pdf

[5] Lambert, V., Pouget, V., Basurko, C., Dallah, F. and Carles, G. (2014) Geophagie et grossesse: état des connaissances et conduite à tenir. Expérience d'une maternité de Guyane francaise. [Geophagy and Pregnancy: Current Knowledge and Management. Clinical Experiences of an Obstetrical Department in French Guiana.] Journal de Gynecologie Obstetrique et Biologie de la Reproduction, 43, 496-503. https://doi.org/10.1016/j.jgyn.2013.06.001

[6] Kmiec, I., N’Guyen, Y., Rouger, C., Beger, J.L., Lambert, D., Hentzien, M., et al. 
(2014) Géophagie chez les femmes VIH+ d'origine africaine connaissances limitées des risques liés à cette pratique. [Geophagia in HIV + Women of African Origin. High Performance and Limited Knowledge of Risks Associated with This Practice.] CHU de Reims.

http://www.infectiologie.com/UserFiles/File/medias/JNI/JNI15/posters/2015-poster -JNI-TROP 10.pdf

[7] Geissler, P., Prince, R. and Levene, M. (1999) Perceptions of Soils Eating and Anemia among Pregnant Women on the Kenyan Coast. Social Science and Medicine, 48, 1069-1079.

[8] Meko, G. (2014) Consommation du kaolin pendant la grossesse et pronostic de l'accouchement. [Consumption of Kaolin during Pregnancy and Prognosis of Childbirth.] Thèse de médecine, Université des montagnes, Bangangté, 88 p.

[9] Legroux, M. (2010) Dépistage et prise en charge de l'anémie des grossesses à bas risques. [Screening and Management of Low Pregnancy Anemia Risks.] Gynécologie et obstétrique. 2010. HAL Id: dumas-00572936. https://dumas.ccsd.cnrs.fr/dumas-00572936/PDF/Memoire legroux.pdf

[10] Tchente, C., Tsakeu, E., Nguea, A., Njamen, T., Ekane, G. and Priso, E. (2016) Prévalence et facteurs associés à l'anémie en grossesse à l'hôpital général de Douala. [Prevalence and Factors Associated with Anemia in Pregnant Women Attending the General Hospital in Do.] Pan African Medical Journal, 25, 133. https://doi.org/10.11604/pamj.2016.25.133.10610

[11] Foumane, P., Esiene, A., Dohbit, S., Mbasso, R., Nsahlai, C. and Ze, M.J. (2016) Kaolin Consumption and the Outcome of Surgery in Women: A Comparative Study of 263 Operations at the Yaounde Gyneco-Obstetric and Pediatric Hospital. International Journal of Reproduction, Contraception, Obstetrics and Gynecology, 5, 4216-4219. https://doi.org/10.18203/2320-1770.ijrcog20164317

[12] Njiru, H., Elchalal, U. and Paltiel, O. (2011) Geophagy during Pregnancy in Africa: A Literature Review. Obstetrical \& Gynecological Survey, 66, 452-459. https://doi.org/10.1097/OGX.0b013e318232a034

[13] Razafimeha, S. (2011) La géophagie: cause insolite d'anémie ferriprive. [Geophagia: A Misleading Cause of Iron-Deficient Anemia.] La Revue Médicale de Madagascar, 1, 2-3. 